\title{
The Square as an Outdoor Market Space: Exploring the potentials of Dataran Merdeka
}

\author{
Khalilah Zakariya, Nor Zalina Harun \\ Dept. of Landscape Architecture, Kulliyyah of Architecture \& Environmental Design, \\ International Islamic University Malaysia, P.O. Box 10, 50728 Kuala Lumpur, Malaysia \\ khalilah@iium.edu.my
}

\begin{abstract}
This exploratory paper presents the potentials of appropriating a temporary weekend market adjacent to a historic square as an informal activity to encourage people to engage more with Dataran Merdeka as their historic place. From employing methods of observations, mapping and interviews, the findings from this paper reveal how locating temporary market activity at Dataran Merdeka might activate this historic square as a lively social space while tapping into the existing event culture. This study suggests that the juxtaposition between the historic and the everyday can ascribe new meaning to the layers of the city's heritage to support cultural sustainability.
\end{abstract}

Keywords: culture; heritage; market; square; urban

eISSN 2398-4295 @ 2018. The Authors. Published for AMER ABRA cE-Bs by e-International Publishing House, Ltd., UK. This is an open-access article under the CC BY-NC-ND license (http://creativecommons.org/licenses/bync-nd/4.0/). Peer-review under responsibility of AMER (Association of Malaysian Environment-Behaviour Researchers), ABRA (Association of Behavioural Researchers on Asians) and cE-Bs (Centre for EnvironmentBehaviour Studies), Faculty of Architecture, Planning \& Surveying, Universiti Teknologi MARA, Malaysia.

DOI: http://dx.doi.org/10.21834/ajbes.v3i10.93 


\subsection{Introduction}

The square is a public open space that serves as a place where the urban community carries out their leisure activities. The city square often functions as a civic space for the communities to gather, engage in leisurely pursuits, and celebrate various activities (Child, 2004; Lynch, 1981; Marcus \& Francis, 1998). Among the squares found in cities, there are those that are more iconic than others because of their historical significance. In Kuala Lumpur, Dataran Merdeka, also known as the Merdeka Square, is an example of an iconic historic urban square that comes in the form of an open field. Since its early development it functions as a green nucleus of the city and as a place for the public to conduct their social and leisure activities (Anbalagan, 1999; Chen, 1998). The Dataran Merdeka's historical background makes it a landmark in Kuala Lumpur and an attraction to tourists.

The pressures from development and demands of urban tourism over the years have resulted in the physical transformations of public spaces, including historic open space. In the 1990s, Dataran Merdeka has undergone similar transformations and morphological changes, where built spaces such as sidewalks, raised platforms, underground parking spaces and retail outlets, large-scale digital screen and various landscape elements were added to the square (Chandran, 2004). The square is not only used annually for hallmark celebrations and concerts such as for the New Year and the Independence Day, but also to host public events such as marathons and parades. While formal events as such become key attractions for locals and tourists, the square remains less active on other days. This is also contributed by the fact that the square is located not in the centre of active commercial and social areas, but tucked rather away from it. Around early to mid-2000s, a hint of informal public use is visible when the main road adjacent to the square is closed from vehicular traffic every Saturday night. Crowds of people who walked from the nearby Lorong Tuanku Abdul Rahman (Lorong TAR) night market appropriated the open field and the main street as their picnic spaces (Khalilah, 2012a). This phenomenon suggests the possibilities of informal public events as a catalyst to activate the historic urban square as a vibrant social and cultural space.

The objective of this exploratory study focuses on examining the potentials of appropriating temporary market as informal activities at Dataran Merdeka to allow people to reclaim the square as their public space. The study uses the Lorong TAR night market as a model of a temporary activity that could potentially activate the historic Dataran Merdeka as an active informal public space. The main concentration of this paper is (i) to speculate the possibilities of juxtaposing an informal temporary market activity adjacent to a formal historic square, and (ii) to expand our appreciation and engagement with historic sites.

\subsection{Literature Review}

\section{Dataran Merdeka as a Historic Open Space}

Dataran Merdeka,formerly known as the Padang Club, is among the earliest open spaces set up by the British in Malaya. This open field was originally intended as a military ground for the police and army, and later adopted as cricket and football field, and a civic square for 
the British and the elite groups (Federal Department of Town and Country Planning, 2005; Shiang, 2002). As a celebration ground, events and formal ceremonies were among the premier events held in this square (Amree, 2007). The parade and events included the involvement of the public through activities such as fireworks, decorations and sports, bullock carts and carriage parade, the flower, fruit and vegetable shows and temporary market set ups (Gullick, 1994).

The morphological study of the Dataran Merdeka reveals that before the adaptation of the field by the British as a parade ground and recreational field, the open field was used by the Chinese settlers as a vegetable farm (Amree, 2007; Gullick, 2000; Ramsayer, 1991). Then during the era of the British colony, the adjacent development around this five-acre field gradually transformed into an administrative district, comprising of shophouses, commercial buildings, markets and places of worship (Wan Hashimah \& Shuhana, 2005). Throughout the years Dataran Merdeka continues to become the city's landmark and focal point for official events, bordered by the renowned buildings such as St. Mary's Church, the Royal Selangor Club, the Sultan Abdul Samad Building, the General Post Office, the High Court, the Survey Department and the Public Work Department (Chandran, 2004; Ramsayer, 1991). The location of Dataran Merdeka sits in the axes of three main roads: Jalan Raja, Jalan Raja Laut and Jalan Sultan Hishamuddin. Although the square is not located within the heart of active commercial and social areas, it is still well connected to Kuala Lumpur's heritage and commercial district at Jalan Tuanku Abdul Rahman and Jalan Masjid India (Nor Zalina \& Ismail, 2008a, 2008b). These two streets are known for their active trading and retail outlets, as well as informal street markets, which attract locals and tourists.

\section{Temporary Market as a Cultural Space}

Temporary market is a form of periodic commercial space where trading activities occur between vendors and visitors (Tangires, 2008; Yeung, 1974). This informal activity promotes cultural and economic diversity in the city, as it becomes a vibrant platform for the interactions of people and exchange of products (Wood, Landry, \& Bloomfield, 2006). Markusen (2006) suggests that in planning for the cultural sustainability of the creative city, the community sector and informal cultural activities also play a significant role. Street vendors and informal markets form part of this informal activity. Cheshmehzangi and Heath (2012, p. 29) find that 'temporary markets promote place-identity in the most dominant manner'. This suggests that temporary market plays a valuable role in sustaining the vibrant image of the city that also reflects the people's culture.

In Malaysia, temporary markets started to operate on a daily basis in the late seventies following the New Economic Policy that encouraged the revival of the economic conditions for small entrepreneurs (Noor Erlina, 2007). The most common form of temporary market found in Malaysia is the night market, which is a "temporary weekly event that usually takes place at available open spaces, and on roads or parking lots that are temporarily closed to allow for its operation" (Khalilah \& Ware, 2010) (refer Fig. 1). Studies on the night market reveal its significant economic contributions to the national economy, by acting as a convenient temporary commercial activity for the community and as an informal hub for 
mobile vendors and hawkers (Muhammad Sabbir, Md. Mahmudul, Abdul Highe, \& Masum, 2013; Nor Khomar, Khursiah, \& Amri, 2011).
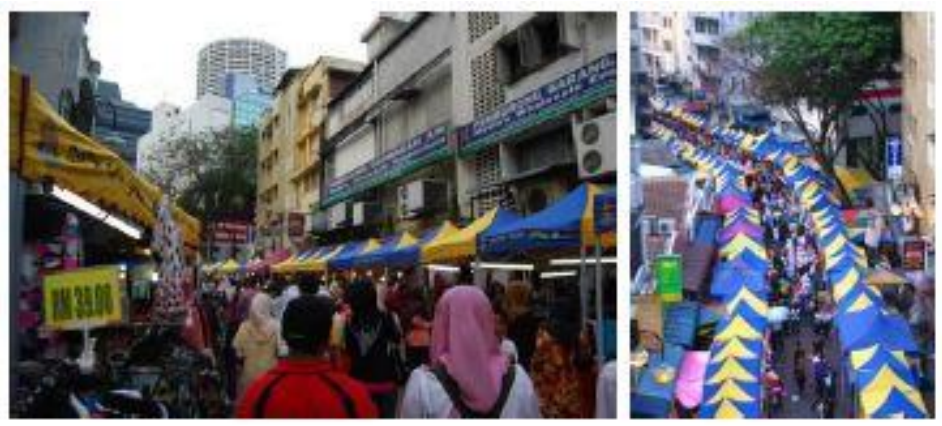

Figure 1: Lorong Tuanku Abdul Rahman Night Market, Kuala Lumpur (Source: Khalilah \& Ware, 2010)

As local and informal commercial space, temporary market has a strong cultural value contributed by its appeal to the public. The plethora of products and market activities compose the dynamic atmosphere of the market (Khalilah, 2012b; Nor Khomar et al., 2011). A spectacle of activities between market vendors and customers portray a form of living culture that has progressed over the years. Whyte (1980) asserts that a good public space should be able to accommodate diverse social activities where people have the chance to interact and mix with each other. The characteristics and identity of a city are displayed through the activities of its people and not merely through a collection of spaces and buildings. As Jacobs (1961, p. 273) writes, "if a city's streets look interesting, the city looks interesting; if they look dull, the city looks dull".

Although the temporary market and historic open space are two different spatial typologies, however, these two spaces share a common identity as they represent the built and lived heritage of a city. Massey (1991, p. 28) contends, "what gives a place its specificity is not some long internalised history but the fact that it is constructed out of a particular constellation of social relations, meeting and weaving together at a particular locus". Norsidah (2010) finds that the perceptual image of a place, combined with physical elements and activities, shape and influence users' attachment towards a place. The coexistence of temporary market at historic open space is not a new idea, as this is present at prominent market squares, such as the Djemaa El Fna in Marrakech.In the daytime, the square is filled with vendors. At night, the square transforms into an active outdoor market. The flexible functions of the Marrakech city square as a temporary market space demonstrate the possibilities of how Dataran Merdeka might be celebrated as a social and cultural space for the public. 


\subsection{Methodology}

Field visits were conducted at Dataran Merdeka and Lorong TAR night market. These two case studies were chosen based on their close adjacencies, walkability between each other and their existing connected activities. Through the stance of participant observers, the researchers engaged in walking and photographing to assimilate the role of the visitor (Robson, 2002), as well as to experience the spatial qualities of Dataran Merdeka and the night market. Nonparticipant observations and mapping were also conducted upon users and spaces of the sites. From the fieldwork, the researchers mapped the spatial characteristics of both sites, which include the physical layout, adjacent contexts, infrastructures and activities (Helsel, 2004; Hood, 1997; Zeisel, 1984). The observation and mapping activities were done during weekdays and weekends to gain a closer look at how the square and the market operate. Semi-structured interviews were conducted with market vendors, visitors and organisers, and people who visit Dataran Merdeka. The aim of this method is to investigate the needs of each user and their perception towards the potentials and challenges of the historic square and the market (Denscombe, 2007; Robson, 2002). Main respondents in this study were representatives from the Kuala Lumpur City Hall, the vendor association, local visitors and foreign tourists at Dataran Merdeka and the Lorong TAR night market.

\subsection{Results and Discussions}

From examining the data collected, three key findings were analysed: (i) availability of common infrastructure between the square and the temporary market, (ii) strategies on juxtaposing the historic and the everyday; and (iii) speculative mapping of the spaces and flows of the activities. Although currently Lorong TAR night market operates at its present location, there is still a possibility that the night market might be relocated in the future due to the pressures of urbanization, as it has been relocated previously. Given this as a probable scenario, the findings of this study are examined on how the cultural activities of the Lorong TAR night market might co-exist with Dataran Merdeka (refer Fig. 2), and how the notion of celebrating history can shift from a passive appreciation to an active engagement by the people.

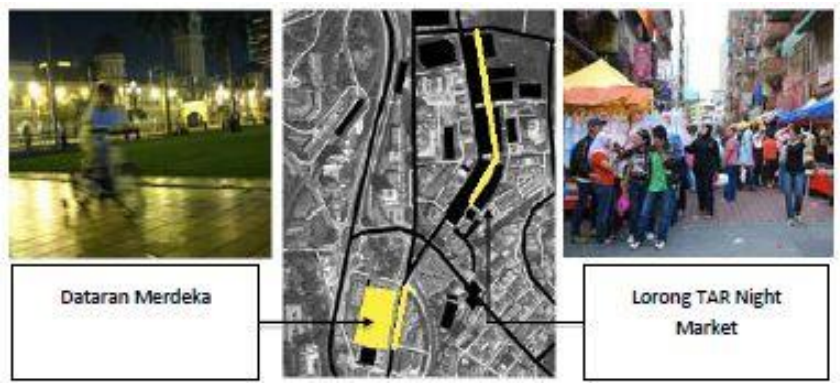

Figure 2: Location of Dataran Merdeka and Lorong TAR night market 


\section{Common Infrastructure}

The night market's operation relies on several hard and soft infrastructures. The hard infrastructures comprise supporting attractions around the market location, hotels, public transportation and vehicular access, Muslim prayer facilities, public toilets and parking spaces. This is also supported by the presence of soft infrastructure, which are the collaborative planning and management process among the Kuala Lumpur City Hall, the vendor association, individual vendors, garbage collecting service and other relevant organisations. The familiarity of Lorong TAR and Jalan Tuanku Abdul Rahman towards locals and tourists and its prominent heritage context largely contributes to the popularity of this market.

This finding is similar to the hard and soft infrastructures found at Dataran Merdeka. Its attraction as a historic city node is also supported by its close vicinity to other well known buildings, convenient public transportation and vehicular access, walkable distance from major tourist attractions (Jalan Tuanku Abdul Rahman, Jalan Masjid India, Masjid Jamek, Central Market and Petaling Street), public toilets and tourist information centre. The soft infrastructure of Dataran Merdeka includes the planning and management of events by the Kuala Lumpur City Hall, Tourism Malaysia and other relevant organisations. While hard infrastructure is found to be essential in operating a temporary event, the provision of soft infrastructure is equally crucial in ensuring the running of the event. The city of Kuala Lumpur demonstrates an example of having a robust policy that recognises the importance of temporary activities in its open spaces.

On the micro scale, Lorong TAR night market operates across more than two kilometres of street space at a back lane behind two rows of commercial buildings. Since the market is temporary, on-site power supplies provided by the city council enable its operation. Dataran Merdeka's five-acre open space and the width of its adjacent main road, Jalan Raja, are ample to host approximately the same number of stalls at Lorong TAR night market, which are more than 500 stalls. Since Dataran Merdeka has previously hosted temporary events, provision of electricity for market vendors can adopt the similar method of tapping into the existing power supply, or through adding-on mobile generator. The physical appearance of the market stalls might also come in different forms as a move towards creating a new city image.

\section{Relocating and Juxtaposing}

Vehicular access to the Dataran Merdeka and Jalan Raja is closed every Saturday night to encourage pedestrians to conduct their leisure activities. This used to be the regular "ritual" route of visitors visiting Lorong TAR night market, where people would gather and sit in the middle of the main road and around the square to enjoy their food in a night picnic. A temporary market model like the Lorong TAR night market has the potential to transform Dataran Merdeka into a festive market space and public space on weekend nights. The juxtaposition between the historic and the everyday can create a striking adjacency between an event that was built in the past and an event that is experienced in the present (refer Fig. 3). This alternative night market location can act as a co-activator for other existing buildings 
around Dataran Merdeka, such as the Kuala Lumpur Library, Kuala Lumpur City Gallery, and the Sultan Abdul Samad building. A recurring weekly or monthly informal event like the temporary market can allow the public to interact closely with the historic square, while gradually shifting the notion of celebrating history from a distant appreciation to a more direct engagement. Locating a market here would also tap into the existing events culture of the site.

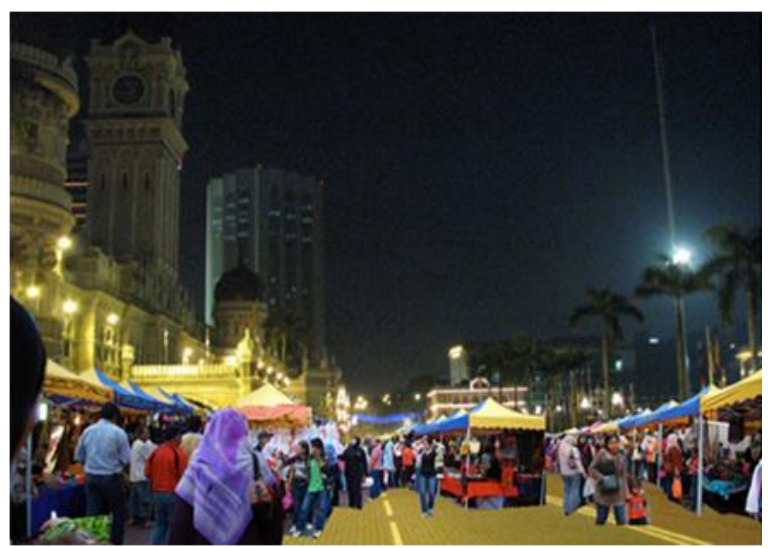

Figure 3: Photomontage of potential temporarymarket activity

\section{Mapping the Spaces and Flows}

The operation of temporary market involves the choreography of spaces and flows. By mapping the anticipated movements of vendors, visitors, vehicles and occupied spaces, the city council and market organisers can plan better the running of the event. Among the common concerns over informal public activities organised in an iconic historic space often points to the management of crowds, garbage and safeguarding of the open field, its built spaces and street furniture. However, the existing managements of both Dataran Merdeka and Lorong TAR night market have proven that with flexible planning and management of the space before, during and after the event, an informal event as such is manageable. These diagrams demonstrate the anticipated procession by vendors and visitors into Dataran Merdeka during the market day (refer Fig. $4 a$ and $4 b$ ). From activating the main road adjacent to the square as a market space, visitors from other nearby commercial areas such as Petaling Street and Central Market might also walk to the square. This then creates new flows of activities towards Dataran Merdeka. 

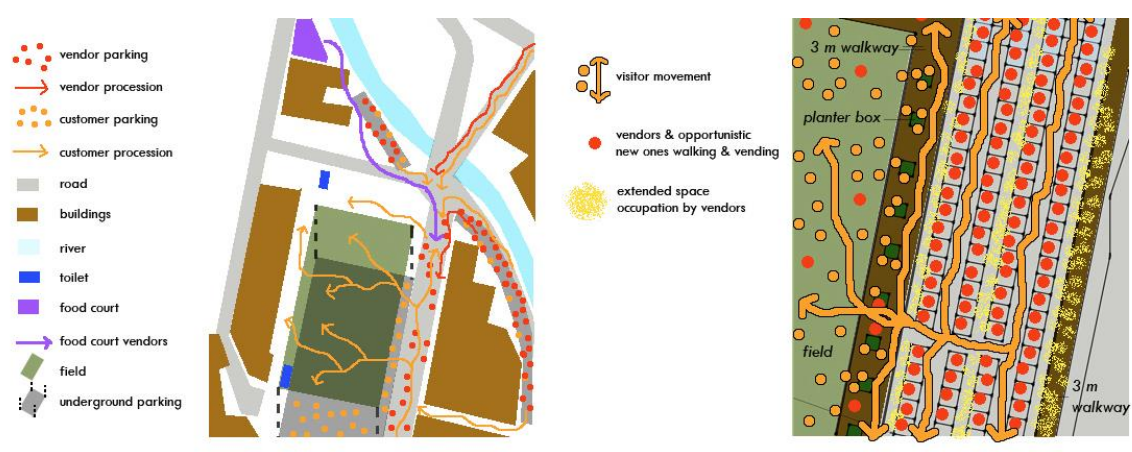

Figure 4: (a) Left: Procession to the night market site at Dataran Merdeka and Jalan Raja by vendors and visitors. (b) Right: Anticipated spillover activities of visitors and vendors on the square

\subsection{Conclusion}

It is important to acknowledge that history, like culture, is not static. Hence, the idea of how a historic space might be occupied should respond to the needs and culture of the contemporary society. Cohen (1993), an anthropologist, alludes to the notion that culture is a process and that it is a product of social processes. The exploratory concept in this paper postulates a different way of positioning historic open space as a public space, which is commonly regarded as being "precious" and "untouchable". The idea that has been discussed throughout this study suggests are more open approach that blends the historic and the everyday. Dataran Merdeka, an independence square as its name suggests, has a significant role to play as "the people's Dataran". Allowing the public to reclaim this square, as their public space where both formal and informal activities can be conducted, is an example of how the concept of independence can be further expanded. Temporary market activities do not only serve as foundations for the informal economy of the country, but also as a melting pot of living and progressive cultures of its people.

The night market is not the only potential temporary activity, but rather an example of a possible informal event. While the market model could become a catalyst for the street life around the square, it is important to foresee the possible ramifications of locating a market space near the square. For instance, by activating the new market in the square, Lorong TAR will eventually become deactivated on weekend nights. This may also shift the movement of shop visitors at Lorong TAR. However, the changes in crowd movements in this area might only be minimal as the shops at Lorong TAR are still regularly operating as daily retail spaces.

Dataran Merdeka is a prominent urban image for Kuala Lumpur and Malaysia. By taking advantage of this historical landmark, the temporary market could borrow the familiarity and identity of its location. At the same time, the significance of this historic square could also be 
reflected upon the vibrant activities of its people. The "conversations" juxtaposed between these two spaces also add to the values of the square and the market. The poetics of space created from locating a modest everyday culture of the market activities alongside the historical landmark also broaden how we value history and culture, both as rich qualities of the city.

\section{Acknowledgement}

The authors wish to record appreciation to International Islamic University Malaysia and Ministry of Higher Education Malaysia for their support in this study.

\section{References}

Amree, A. (2007, 19 August 2007). Padang banyak melahirkan jaguh sukan, Akhbar Kosmo, p. 12.

Anbalagan, V. (1999, 31 December 1999). Century-old padang steeped in history, New Straits Times.

Chandran, J. (2004). The padang: Kuala Lumpur in Kuala Lumpur: corporate, capital, cultural cornucopia. Kuala Lumpur: Arus Intelek Sdn.Bhd.

Chen, V. F. (1998). The Encyclopedia of Malaysia: Architecture (Vol. Vol. 5). Singapore: Archipelago Press.

Child, M. C. (2004). Squares: A public place design guide for urbanists. New Mexico: University of New Mexico Press.

Cohen, A. P. (1993). Culture as identity: an anthropologist's view. New Literary History, Vol. 24(No. 1), pp. 195-209.

Denscombe, M. (2007). The good research guide: for small-scale social research projects. Maidenhead: McGrawHill.

Federal Department of Town and Country Planning. (2005). Open spaces in Urban Malaysia. Kuala Lumpur: Ministry of Housing and Local Government Malaysia.

Gullick, J. M. (1994). Old Kuala Lumpur. Shah Alam: Oxford University Press.

Gullick, J. M. (2000). A history of Kuala Lumpur 1857-1939. Selangor: Malaysian Branch of the Royal Asiatic.

Helsel, S. (2004). Taipei Operations. Taipei, Taiwan: Ti-Nan Chi / Human Environment Group.

Hood, W. (1997). Urban diaries. Washington, DC: Spacemaker Press.

Jacobs, J. (1961). The death and life of great American cities. New York: The Modern Library.

Khalilah, Z. (2012a). Fleeting feast: Mapping and accommodating temporary markets. PhD Thesis. RMIT University. Melbourne.

Khalilah, Z. (2012b). Hard and soft infrastructures of temporary markets. In I. Zen, J. Othman, M. Mansor \& N. Z. Harun (Eds.), Nurturing nature for man. Gombak: International Islamic University Malaysia. 
Khalilah, Z., \& Ware, S. A. (2010). Elasti(c)ity: rediscovering the night market as an itinerant urban space. Paper presented at the 1 st International Conference on Sustainable Architecture \& Urban Design, Penang, Malaysia.

Lynch, K. (1981). Good city form. Cambridge: The MIT Press.

Marcus, C. C., \& Francis, C. (1998). People places (Second ed.). New York: John Wiley \& Sons, Inc.

Markusen, A. (2006). Cultural planning and the creative city. Paper presented at the The Annual Amercial Collegiate Schools of Planning Meetings, Fortworth, Texas.

Massey, D. B. (1991). A global sense of place. Marxism Today, (June), pp.24-29. Retrieved from

Muhammad Sabbir, R., Md. Mahmudul, H., Abdul Highe, K., \& Masum, M. (2013). Ethics in Business: Practices by the Street Hawkers. Journal of Management Research, 5(1).

Noor Erlina, I. (2007). Mengkaji perletakan lokasi pasar malam dan perkaitannya di antara faktor sosio-ekonomi masyarakat setempat menggunakan teknik aplikasi sistem informasi geografi/GIS: satu kajian kes di Cheras. Jabatan Geografi, Fakulti Sastera dan Sains Sosial. Universiti Malaysia. Kuala Lumpur.

Nor Khomar, I., Khursiah, A. A., \& Amri, A. (2011). Dynamism of a night market. Journal of Case Research in Business and Economics, 4.

Nor Zalina, H., \& Ismail, S. (2008a). Morphology of Padang: A case study of Dataran Merdeka, Kuala Lumpur. Paper presented at the International Seminar in Sustainable Environment \& Architecture (SENVAR), Shah Alam.

Nor Zalina, H., \& Ismail, S. (2008b). Role and fate of 'padang' in Malaysian historical cities. Paper presented at the 5th Great Asian Street Symposium, National University of Singapore.

Ramsayer, C. (1991). Kuala Lumpur Trough the looking glass: Around the Padang (Vol. IV).

Robson, C. (2002). Real World Research: A Resource for Social Scientist and Practicioner-Researchers. Oxford: Blackwell Publishing.

Shiang, H. L. (2002). A comparison on urban spatial structures of the British Colonial port cities among Calcutta, Georgetown and Singapore. Paper presented at the The Penang Story Conference, Georgetown, Pulau Pinang.

Tangires, H. (2008). Public markets. New York: W.W. Norton \& Company, Inc.

Wan Hashimah, W. I., \& Shuhana, S. (2005). The old shophouses as part of Malaysian urban heritage: The current dilemma. Paper presented at the 8th International Conference of the Asian Planning Schools Association, Penang.

Whyte, W. H. (1980). The social life of small urban spaces. Washington D. C.: The Conservation Foundation.

Wood, P., Landry, C., \& Bloomfield, J. (2006). Cultural diversity in Britain: A toolkit for cross-cultural cooperation. York: The Joseph Rowntree Foundation.

Yeung, Y. M. (1974). Periodic markets: comments on spatial-temporal relationships. The Professional Geographer, 26(2), 147-151.

Zeisel, J. (1984). Inquiry by design: tools for environment behavior research. New York: Cambridge University Press. 